Teachers

Tin usurensiry or

\title{
and Curriculum
}

KAIAKO ME TE MARAUTANGA

VOLUME 102007

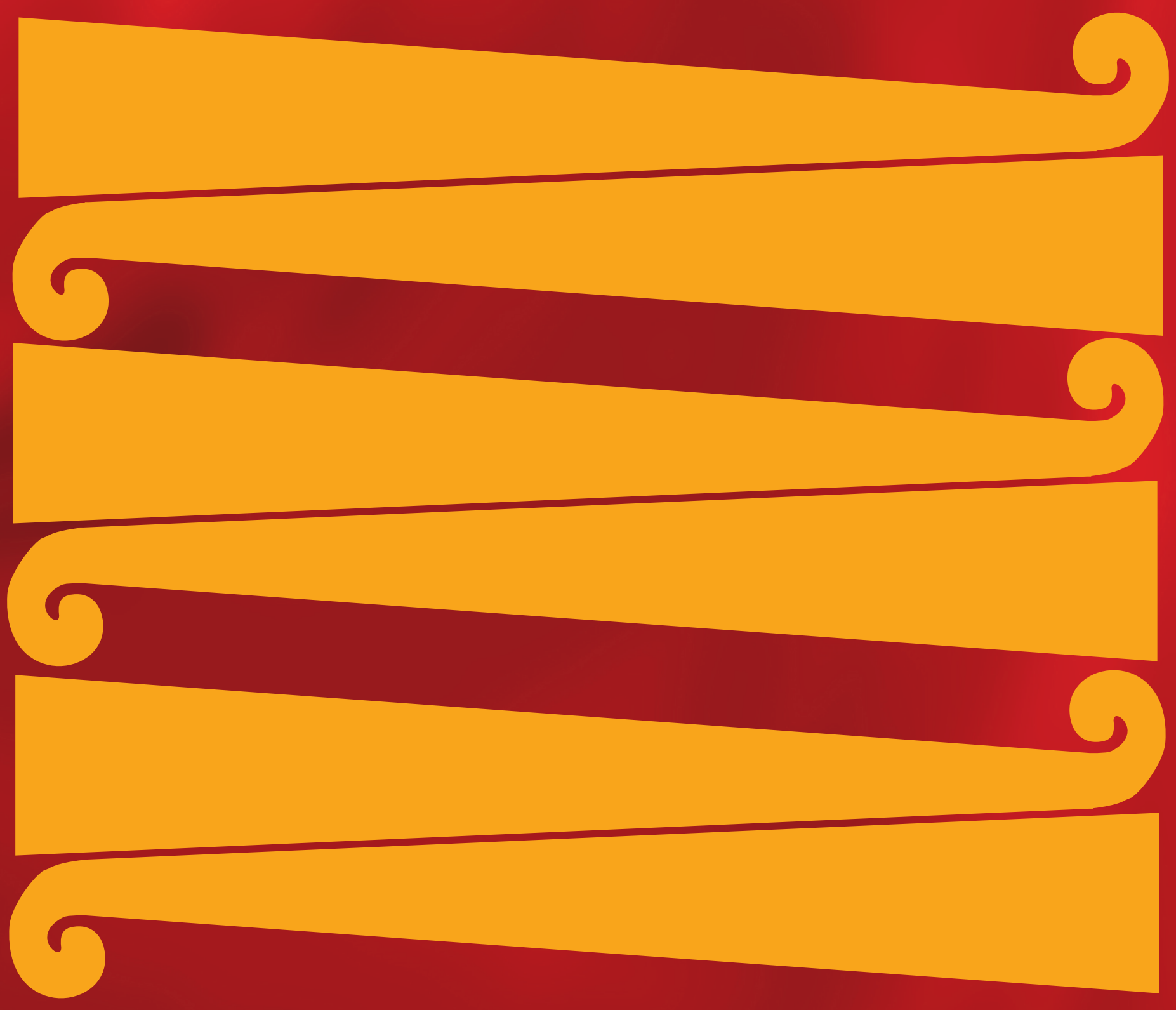




\section{TEACHERS AND CURRICULUM}

EDITOR:

VOLUME 102007

Catherine Lang

Greg Lee (from 2008)

Contents

EDITORIAL COMMITTEE:

Marilyn Blakeney-Williams

Nigel Calder

Ken Carr

Catherine Lang

Greg Lee

Howard Lee

Merilyn Taylor

Hine Waitere

\section{Cover Design ANd ILlustrations}

Donn Ratana

\section{LAYOUT AND DEsign}

Barbara Hudson

\section{EDITORIAL CORRESPONDENCE AND} MANUSCRIPTS SUBMITTED FOR PUBLICATION should be addressed to:

Greg Lee

School of Education

The University of Waikato

Private Bag 3105, Hamilton

New Zealand

email: educgdl@waikato.ac.nz

\section{WeBsite:}

http://education.waikato.ac.nz/research/ publication/

BOoKS FOR REVIEW should be sent to the editor.

\section{BUSINESS CORRESPONDENCE:}

orders, back orders, subscriptions, payments and other enquiries should be sent to:

\section{TeaChers AND CURRICULUM}

Hamilton Education Resource Centre

PO Box 1387

Hamilton

email: janh@waikato.ac.nz

\section{SUBSCRIPTIONS:}

within New Zealand \$22 (includespostage)। overseas $\$ 40$ (includes postage)

\section{COPYRIGHT:}

School of Education

The University of Waikato

\section{EDITORIAL}

Catherine Lang

\section{OPINION}

Reflections on educational change in New Zealand Noeline Alcorn

Four Māori girls and mathemetics: What can we learn from them? Merilyn Taylor,Ngarewa Hawera, Jenny Young-Loveridge \& Sashi Sharma

Is the PROBE reading assessment an effective measure of reading comprehension? Qin Chen \& Ken E. Blaiklock

Scholarship in the design of curriculum and the professional practice of tertiary teaching - a personal perspective Anne Hume

Learning styles and other modern myths Ivan Snook

\section{COMMENT}

Some reflections on the New Zealand Curriculum, 2007

Gregory Lee \& Howard Lee

The timid curriculum Ivan Snook

Comment on the New Zealand Curriculum Irene Cooper \& Sandra Aikin

Social Sciences in the New Zealand Curriculum: A case of arrested development? Mediating challenges ahead Philippa Hunter

Health and Physical Education and the New Zealand Curriculum 2007: Ongoing challenges Katie Fitzpatrick

Twenty-first century schools with nineteenth and twentieth century curriculum and tools

Nadine Ballam

\section{BOOK REVIEW}

The hidden lives of learners, by Graham Nuthall Reviewed by Colin Gibbs 
Teachers ANd Curriculum is an annual publication of the School of Education, The University of Waikato, Hamilton, New Zealand.

It includes articles about curriculum issues, research in the area of curriculum and informed curriculum practice. Reviews of curriculum related books may also be included.

The Opinion item is contributed by a leading New Zealand educationalist.

ISSN 1174-2208

\section{NOTES FOR CONTRIBUTORS}

Teachers and Curriculum provides an avenue for the publication of papers that:

- raise important issues to do with the curriculum

- report on research in the area of curriculum

- provide examples of informed curriculum practice

- review books that have a curriculum focus.

This peer reviewed journal welcomes papers on any of these from tertiary staff and students, teachers and other educators who have a special interest in curriculum matters. Papers on research may be full papers, or if time or space is at a premium, research notes, that is a 2,000 word summary.

\section{SUBMITTING ARTICLES FOR PUBLICATION}

The editorial committee encourages contributors to ask colleagues to comment on their manuscripts, from an editorial point of view, before submission for publication.

\section{LENGTH}

Manuscripts should not normally exceed 7,000 words, includng references and appendices. An abstract must be provided. Abstracts should not be more than 100 words.

\section{METHOD OF SUBMITTING A PAPER}

Please provide copy in 12 point type in a font compatible with the use of macrons (preferably Helvetica Maori or Times Maori) with line and a half spacing for the main text, and with $20 \mathrm{~mm}$ margins on all edges. Word files are preferred. Please do not include running headers or footers, Follow the style of referencing in the Publication Manual of the American Psychological Association (APA), 5th edition with references in a reference list at the end of the manuscript, rather than footnotes. Manuscripts not submitted in accordance with the above guidelines will be returned to authors for amendment.

\section{Covering LetTer}

When submitting a manuscript to Teachers and Curriculum, authors must, for ethical and copyright reasons, include in a covering letter a statement confirming that (a) the material has not been published elsewhere, and (b) the manuscript is not currently under consideration with any other publisher.

\section{DATE FOR SUBMISSION}

Manuscripts may be submitted at any time.

\section{COPYRIGHT}

Copyright of articles published in Teachers and Curriculum rests with the School of Education, The University of Waikato. Requests to reprint articles, or parts of articles must be made to the Editor via the Hamilton Education Resource Centre. Email: barbh@waikato.ac.nz

\section{ACKNOWLedgement Of ReVIeWers}

We wish to thank the following people who reviewed for this edition of Teachers and Curriculum. Asterisks indicate reviewers who contributed more than one review.

Guy Broadley
Ken Carr
Wendy Carss
Gail Cawkwell
Linda Daniell
Colin Gibbs*
Ted Glynn
Paul Keown
Catherine Lang*
Greg Lee*
Peggy Lee
Clive McGee*
Colleen McMurchy-Pilkington
Ally Sewell
Gordon Suddaby




\section{Health and Physical Education and The New Zealand CurRiculum 2007: ONGOING CHALLENGES}

Katie FitzPatrick

SCHOOL OF EdUCATION

THE UNIVERSITY OF WaIKaTO

\begin{abstract}
INTRODUCTION
New Zealand has a new curriculum document for all schools. The $2007 \mathrm{New}$ Zealand curriculum deviates from previous curriculum documents established throughout the 1990s by including all subject areas into one single booklet. It includes generic sections on Values, Key Competencies and Principles and then details each learning area (English, The Arts, Health and Physical education, Learning Languages, Mathematics and Statistics, Science, Social Sciences, Technology). Descriptions of each subject discipline are one or two pages long, with additional achievement objectives included, describing the expected learning at each year level.
\end{abstract}

I recorded my concerns a year ago in this journal (Fitzpatrick, 2006) about the place of health and physical education in schools in relation to the then draft version of this curriculum (Ministry of Education, 2006). My discussion focused primarily around two areas. First, the brief nature of this new curriculum document and the potential consequences of this for health and physical education in schools. Second, the place of the Māori concept of Hauora in the pages relating to health and physical education, and the significance of ignoring recent debates surrounding the inclusion of Mãori concepts in mainstream curricula. My concerns have not changed with the final publication of the New Zealand Curriculum (Ministry of Education, 2007).

Space here does not afford a broad discussion of all the issues surrounding health and physical education in this policy document. One issue, however, stands out, that is the place of the Māori notion of Hauora, named as one of the underlying concepts in health and physical education in the new curriculum document. Hauora has been the subject of fierce debate in recent years among physical education scholars and practitioners. I will briefly foreground this debate before discussing Hauora in relation to the new curriculum.

\section{Background: Hauora in Health aNd PE, 1999 AND 2007}

In 1999, the New Zealand Ministry of Education published a new curriculum for health and physical education (Ministry of Education, 1999). This document signalled a shift in thinking in health and physical education by, among other things, communicating an overt socio-cultural and critical approach to these disciplines in schools. The 1999 curriculum writers communicated this new direction predominantly through four underlying concepts. Each of the concepts: 'Hauora', the 'Socio-Ecological Perspective', 'Health Promotion' and 'Attitudes and Values' was afforded a full page in the 1999 curriculum and illustrated diagrammatically (for discussion of this shift and the other three concepts see Burrows \& Wright, 2004; Culpan, 1996/97; Penney \& Harris, 2004; Tasker, 1996/97). Significantly, one of these concepts attracted more attention in scholarly writing and debate than the others. By including the Māori concept of Hauora as one of the underlying concepts and foundational philosophies of teaching and learning in New Zealand health and physical education, the writers began a debate about the place of Mãori concepts in state-sponsored curriculum documents. The model of Hauora draws on Mason Durie's (1994) Te Whare Tapa Wha (four sided house) and includes walls made up of Taha Tinana (physical wellbeing), Taha Hinengaro (mental and emotional wellbeing), Taha Whanau (social wellbeing), and Taha Wairua (spiritual wellbeing). Hauora is explained in the 1999 curriculum statement as "a Māori philosophy of health unique to New Zealand" (Durie, 2004, p. 31) and is linked with 'wellbeing'.

Hauora is also named in the 2007 New Zealand Curriculum (Ministry of Education, 
2007) in the two pages now afforded health and physical education. It appears as part of a list of the four underlying concepts (named above) and is described as "a Māori philosophy of well-being that includes the dimensions taha wairua, taha hinengaro, taha tinana, and taha whanau, each one influencing and supporting the others" (Ministry of Education, 2007, p. 22). It also appears in the glossary which reads: "in health and physical education, the use of the word Hauora is based on Mason Durie's Te Whare Tapa Wha Model (Durie, 1994). Hauora and wellbeing, although not synonyms, share much common ground. Taha Wairua relates to spiritual wellbeing; Taha Hinengaro relates to mental and emotional wellbeing; Taha whanau relates to social wellbeing; Taha Tinana relates to physical wellbeing" (Ministry of Education, 2007, inside back cover).

In the years between these two curriculum documents, scholars responded specifically to the inclusion of the Mãori concept of Hauora in the 1999 curriculum, and criticism was levelled at the writers on several fronts. George Salter spoke out about what he saw as the misrepresentation of Hauora in the 1999 curriculum, stating that the concept had been 'sanitised' for the mainstream. He raised concerns about the use of such knowledge out of its cultural context, stating that Pākehā curricula do not generally embrace, let alone acknowledge, Māori views of knowledge, teaching and learning (see Salter, 2000). Salter (2000) also found the representation of Hauora in the 1999 curriculum simplistic and he feared that many teachers would not learn the depth of meaning in the concept as it pertains to Mãori. Ross (2001) agreed with this perspective and lamented the barren representation of Hauora in the 1999 curriculum, and the failure of the writers to evoke the depth of understanding inherent in the concept. According to Salter (2000), at best the misrepresentation would result in a general lack of understanding and miscommunication; at worst, it could represent a misappropriation of Māori knowledge, adding further injustice to a long history of colonisation.

Brendan Hokowhitu (2004) later critiqued the inclusion of Hauora in the 1999 curriculum, describing it as an insulting tokenistic gesture, even going so far as to compare it with Freire's concept of 'cultural invasion' (p. 78). Linking the 1999 curriculum and Hauora to the wider political debate, Hokowhitu also criticised the writers' treatment of the Whare Tapa Wha model, describing as remiss the exclusion of 'whenua' (land) in the representation of the model. He speculated that this was a deliberate political decision consistent with wider governmental sensitivity over ongoing Māori land grievances, and a further denial of the integral nature of land to Māori.

Early on, the 1999 curriculum writers justified the inclusion of Hauora on the grounds of its bicultural philosophy (Culpan, 1996/1997; Tasker, 1996/1997) and as a result of the extensive consultation carried out with Māori communities prior to the publication of that policy. Ian Culpan (1996/97), one of the authors, explained

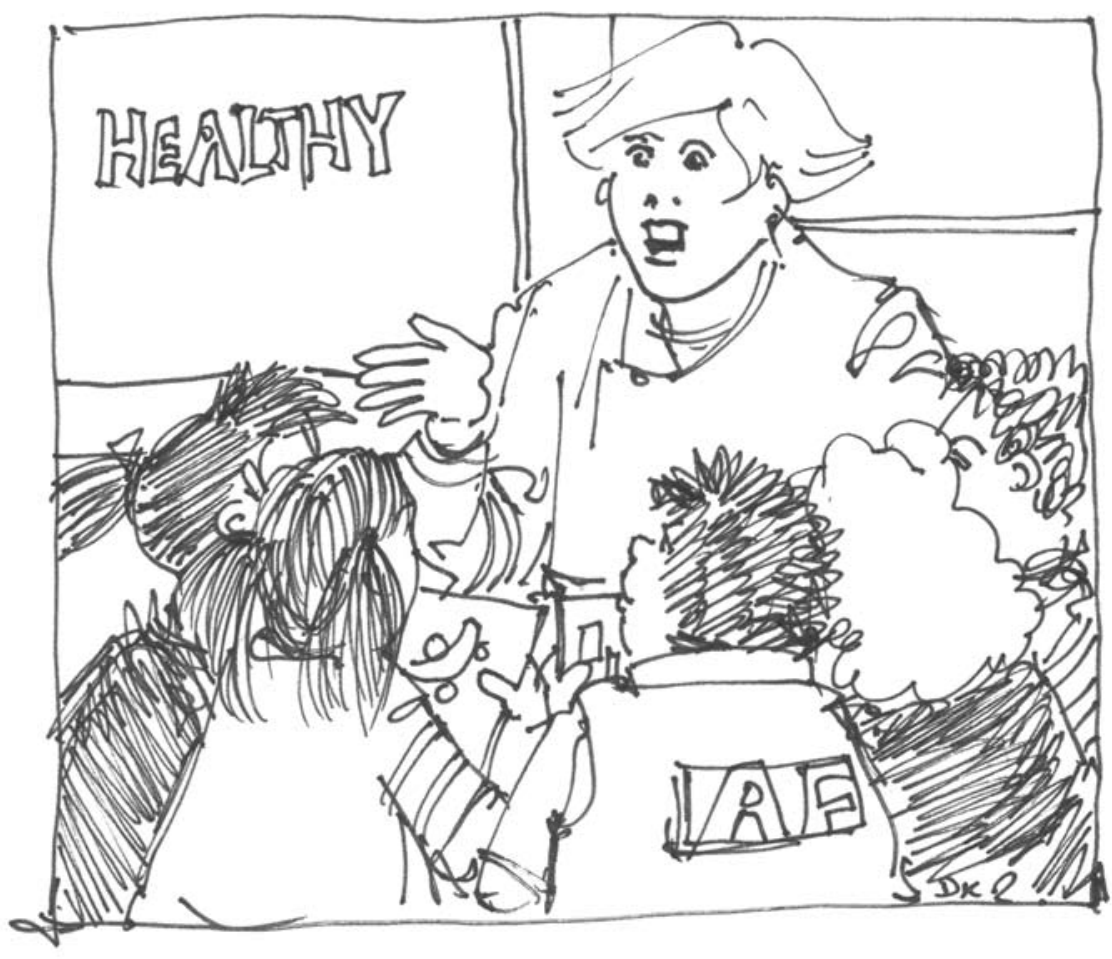

that Hauora assisted them to move away from a purely medicalised and scientised form of physical education, and to embrace more diverse and holistic approaches (Culpan, 1996/1997; Tasker, 1996/1997). Hokowhitu (2004) insisted, however, that the level of consultation with Māori was inadequate. He also argued that "Māori were of the opinion that Hauora was not the most appropriate concept upon which to base a health and physical education curriculum" (p. 78).

Despite the broad philosophies of the 1999 document being supported by international physical education scholars and a related applauding of the attempt at biculturalism (Tinning, MacDonald, Wright \& Hickey, 2001), there remained concern about the 'thin' and decontextualised description of Hauora in the 1999 health and PE curriculum. According to Kohere (2003), translating Hauora as 'wellbeing' is inadequate. The concept is much deeper, amounting to "the driving force for the unfolding of the potential of individuals to act in this world for and with others" (p. 23).

These scholars seem to agree on one thing, that the representation of the Māori concept of Hauora in the 1999 curriculum was a necessary but not sufficient development. It lacked cultural context and, read alone, did not appear to allow for deeper understandings consistent with a Māori world view. Practitioners I know personally echoed this concern. Teachers and students, in my own experience and research (Fitzpatrick, 2006) welcomed the concept of Hauora represented by the Te whare tapa wha model but many felt limited by the lack of further resources and a deeper understanding of the concept. In light of these debates, it is therefore surprising and disappointing to note that the numerous concerns raised about Hauora in the 1999 curriculum were never seriously revisited or addressed in the 2007 curriculum. Partly, this is due to the process of curriculum development and the lack of consultation therein.

\section{HAUORA IN THE 2007 CURRICULUM: PROCESS AND PRODUCT}

As I noted in 2006, the process of writing the health and PE pages of the new document (of which I was a part) was fraught and delimited. I will not discuss this in detail here, except to reiterate that planned consultation with Māori did not happen, bar a half-day meeting with the writers of the Marautanga Māori medium curriculum draft 'Hauora' (Ministry of Education, 2000). After brief discussion, this group recommended broad consultation with community groups. To my knowledge, 
in-depth and reciprocal consultation was never planned and certainly never happened.

The consultation surrounding the 1999 curriculum development included regional meetings between community groups, including specific Māori communities, and the writers. This process was later critiqued because Māori did not have input at inception but rather gave feedback after the document was drafted and were, therefore, not an integral part of curriculum development. Surprisingly, neither of these possible processes happened during the most recent curriculum development in the case of health and physical education. The Ministry of Education rather relied on individuals and groups to feedback on the draft document in writing and within a short timeframe in late 2007. These contributors received no feedback about how their submissions impacted on the final curriculum document. Indeed, Hokowhitu's accusation that the concept of Hauora is used in curriculum in a tokenistic and insulting way has in no way been addressed, and has possibly been reinforced. Not only has there been no meaningful collaboration between Māori and Pakeha over this new curriculum, Māori have not even been consulted over the place and contentious representation of Hauora in health and physical education or given an opportunity to discuss whether this concept is even (still) appropriate.

What is perhaps most surprising with the inception of the 2007 curriculum, is the lack of recognition of the debates surrounding the concept of Hauora, both in the document itself and in the supporting discussions, commissioned articles and meetings held by the Ministry of Education. The result is a complete lack of recourse to any kind of action addressing the concerns of cultural appropriation and marginalisation raised in earlier academic debates.

\section{Final thoughts}

When the decision was made to condense the seven curriculum documents developed throughout the 1990s into one document, health and physical education was reduced in 2007 policy from the 64 pages outlined in the 1999 curriculum document to the mandated two pages (with additional achievement objectives). The consequence of this practical decision is a minimalist representation of a complex and unique learning area. One concept included in this policy is the Mãori concept of Hauora. In relation to Hauora, the decision to decrease, rather than increase content and explanation, directly challenges calls for greater understanding and a more in-depth representation of a concept which comes from a Māori world view, as highlighted in previous academic debates. Although policy documents may not be the best or only ways of accessing knowledge and understanding, the direction set by policy often preludes further action. The key point here is that the inadequate representation of Hauora in the 1999 curriculum reinforced cultural power relations via appropriation of indigenous knowledge. And yet, for all its identified limitations, it was also a bold move which challenged teachers and students to consider a more holistic perspective of health and physical education and one which clearly and deliberately incorporated, however inadequately, a Māori world view. The debate that followed the release of the 1999 curriculum document, though fierce, was thus healthy. The new 2007 curriculum, however, has completely failed to acknowledge either the previous academic debates and/or the related complexity of the concept of Hauora. For such an influential document, this is simply remiss. As Stephen Ball (1990) reminds us, policy making is a messy, ad hoc and political process and the $2007 \mathrm{New}$ Zealand Curriculum document consultation and subsequent development clearly demonstrates this. As a result, the 2007 curriculum has demonstrably failed health and physical education by neither contributing to nor furthering the debate about the importance of Hauora and its critical contribution to the subject area. How to move this debate forward, rather than simply ignoring it and/or closing it down, is now the principal challenge we face in health and physical education as one result of the reductionist and essentially ethnocentric characteristics of the 2007 curriculum document.

Katie Fitzpatrick is a lecturer in health and physical education in he School of Education at the University of Waikato. She may be contacted at katief@ waikato.ac.nz

\section{REFERENCES}

Ball, S. J. (1990). Politics and policy making in education: Explorations in policy sociology. London: Routledge.

Burrows, L., \& Wright, J. (2004). The discursive production of childhood, identity and health. In J. Evans, B. Davis \& J. Wright (Eds.), Body knowledge and control: Studies in the sociology of physical education and health. (pp. 83-95). London: Routledge.

Culpan, I. (1996/1997). Physical education: Liberate it or confine it to the gymnasium? Delta, 48(2), 203-219.

Durie, M. (1994). Whaiora: Māori health development. Auckland, New Zealand: Oxford University Press.

Fitzpatrick, K. (2005). Hauora and physical education in New Zealand: Perspectives of Mäori and Pasifika students. Waikato Journal of Education. 11 (2).

Fitzpatrick, K. (2006). The dangers of minimalism: Health and physical education in the draft New Zealand curriculum. Teachers and Curriculum, vol(issue), pp?.

Hokowhitu, B. (2004). Challenges to state physical education: Tikanga Māori, physical education curricular, historical deconstruction, inclusivism and decolonisation. Waikato Journal of Education, 10, 71 - 84.

Kohere, R. (2003). Te Hauora. In B. Ross \& L. Burrows (Eds.), It takes two feet: Teaching physical education and health in Aotearoa/ New Zealand (pp. 21-23). Palmerston North, New Zealand: Dunmore Press.

Ministry of Education. (1999). Health and physical education in the New Zealand curriculum. Wellington, New Zealand: Ministry of Education.

Ministry of Education. (2006). The New Zealand curriculum: Draft for consultation 2006. Wellington, New Zealand: Learning Media.

Ministry of Education (2007). The New Zealand curriculum. Wellington, New Zealand: Ministry of Education. 
Penney, D., \& Harris, J. (2004). The body and health in policy: Representations and recontextualisation. In J. Evans, B. Davis \& J.Wright (Eds.), Body knowledge and control: Studies in the sociology of physical education and health. (pp. 96-111). London: Routledge.

Ross, B. (2001). Visions and phantoms: Reading the New Zealand health and physical education curriculum. Journal of Physical Education New Zealand, 34(1), 3-14.

Salter, G. (2000). Marginalising indigenous knowledge in teaching physical education: The sanitising of hauora (well-being) in the new health and physical education curriculum. Journal of Physical Education New Zealand, 33(1), 6-16.

Tasker, G. (1996/1997). For whose benefit? The politics of developing a health education curriculum. Delta, 48(2), 187-202.

Tinning, R., MacDonald, D., Wright, J., and Hickey, C. (2001). Becoming a Physical Education Teacher: Contemporary and Enduring Issues. Frenchs Forest, Australia: Pearson Education. 